Article

\title{
A Practical Case Report on the Node Point of a Butterfly Model Circular Economy: Synthesis of a New Hybrid Mineral-Hydrothermal Fertilizer for Rice Cropping
}

\author{
Mei-Yun Chang and Wu-Jang Huang * (]) \\ Department of Environmental Engineering and Science, National Ping-Tung University of Science and \\ Technology, Ping-Tung County 912, Taiwan; mei4933@yahoo.com.tw \\ * Correspondence: wjhuang@mail.npust.edu.tw; Tel.: +886-8-7703202-7076; Fax: +886-8-7740256
}

Received: 14 January 2020; Accepted: 5 February 2020; Published: 9 February 2020

\begin{abstract}
With the increased importance of a circular economy in the world, in this paper we present a practical "butterfly model" (proposed by the Ellen MacArthur Foundation) case report: to gain extra benefits in rice cropping through hybridizing green products of mineral waste and agricultural waste recycling. Hydrothermal biorefinery was used to turn spent agricultural biomass into a value-added biomass nutrient solution (BNS). BNS and sericite mineral waste were mixed and used as a new hybrid mineral-hydrothermal fertilizer for rice cropping. The most important extra benefit of this new hybrid mineral-hydrothermal fertilizer was that the empty grains could be reduced to 1-4 grains/spike (normally, it is 12-18 grains/spike), without significantly decreasing the panicle weight or spike saturation. This case report provides a new logic for circular design at the "node" point of a butterfly diagram.
\end{abstract}

Keywords: butterfly model; circular economy; agricultural waste; mineral waste

\section{Introduction}

With a worsening solid waste problem, reducing agricultural and mineral waste through circular designs is now a rising trend [1]. The Ellen MacArthur Foundation has proposed a butterfly model for a circular economy. Recycling and reusing waste from household, industrial, and agricultural sources and returning waste to its own original application area in a closed-loop system has been practiced for a long time. In this paper, we present a practical case report at the node point of the "butterfly model". With consideration of the safety of waste, we demonstrate a case on the laboratory scale for crossing systems to gain extra benefits in rice cropping through hybridizing green products of mineral waste and agricultural waste recycling.

Agricultural waste output is approximately 4 million tons every year in Taiwan [2]. The composition of this waste (sugarcane exocarp, peanut shells, and rice husks) is lignocelluloses, cellulose, hemicelluloses, and lignin. In recent years, most agricultural biomass research has concentrated on a single type of lignocelluloses [3-7], for example, in applications to prepare high-strength ecological materials, soil improvers, and graphene-containing carbon materials $[8,9]$. These lignocelluloses' structures do not easily break up and require chemical or physical degradation. If this biomass is burned, then it becomes a source of environmental pollution. Using high temperature or pressure does not require the addition of chemicals or requires only the addition of non-toxic chemicals that can be recycled, resulting in reduced environmental pollution [10].

Sericite is one of the most commonly altered minerals from the hydrothermal ore-forming process. It is a rich and low-cost material widely used in thermoplastics, cosmetics, food packaging, toys, and 
automobile coatings [11,12]. In recent years, sericite has been the focus of many scholars' attention as an electric insulator [13], in its use for improving the adsorption of strontium [14-18], and for its ability to remove cesium, copper, lead, cadmium, phenol, and nickel heavy metal ions [19].

Sericite and agricultural waste contain silicon (Si) and potassium (K); they could be used in soil to enhance the stress tolerance of a wide variety of crops, as they could greatly boost rice yield and mitigate abiotic stress, especially from a drought [20]. Research results have confirmed that, under saline conditions, silicon could prove to be a better strategy for maintaining crop productivity [21-25]. The addition of Si fertilizer can alleviate K-deficiency-induced growth inhibition by improving the plant's water status via enhancement of stomatal conductance and transpiration rates such as number of grains per panicle, seed-setting rate, and 1000-grain weight [3]. In summary, the beneficial effect of silicon applied to soil or as a foliar application has been well recognized.

In recent years, the decline in rice yields as a result of excessive chemical fertilizer (CF) inputs is a matter of great concern in rice-growing regions of Asia [26]. Subtropical and tropical soils are generally low in available $\mathrm{Si}$ [27]. Heavy metal pollution in paddy soil also results in retardation and yield losses [28]. Therefore, from the viewpoint of circular design for agriculture, we can consider the application of silicon-containing mineral waste such as sericite to promote crop growth. This study used a cellulosic biomass nutrient solution (BNS) made from the hydrothermal carbonization (HC) of agricultural waste, as described in our previous investigations [29,30], and sericite mineral waste to enhance rice growth by reducing empty grains.

\section{Experimental Section}

\subsection{Sample Preparation and Characterization}

The agricultural waste biomass (sugarcane exocarp, peanut shells and rice husks) was crushed separately and mixed equally in a ratio of 1:1:1 (100 g each, total was $300 \mathrm{~g})$. This was used to create the BNS in a $6.0 \mathrm{~L}$ hydrothermal carbonization reactor at $200^{\circ} \mathrm{C}$ and $15 \mathrm{~atm}$ for $1 \mathrm{~h}$.

Sericite powder was provided by the manufacturer. Peanut shells, sugarcane exocarp, and rice husks were obtained from a farm in Tainan city (Taiwan). The morphology and chemical composition of the powder samples were analyzed using a scanning electron microscope (SEM, JSM-6700F, Japan) and energy dispersive spectrometers (EDX, S-3000N, HITACHI, Japan). Soil phase and heavy metal analysis by ion coupled plasma spectrometry(ICP) were used to characterize the chemical composition of the BNS liquid.

\subsection{Rice Growth Experiments}

In the rice growth experiment, rice seeds were planted in plastic pots in the net-house of a laboratory at the campus of National Pingtung University of Science and Technology (NPUST, DMS: $22^{\circ} 38^{\prime} 27^{\prime \prime} \mathrm{N}, 120^{\circ} 35^{\prime} 44^{\prime \prime} \mathrm{E}$ ), and different fertilizers were applied after seeding for one season (March 5, 2017 to July 5, 2017). The different fertilizers used in the rice growth experiment were set as: a control group for water (Ck), sericite (EX1), BNS (EX2), and a BNS/sericite mixture (EX3), which was based on the experiment being a comparison of the effects of different additives on rice.

Rice seed (Taiwan Terrier No. 9, the most popular applied species) was obtained from farmers. The details of rice cropping are described in the following, for example: In one pot, five rice seeds were used. A volume of $100 \mathrm{~mL}$ of the BNS was mixed with 40 and $30 \mathrm{~g}$ of sericite, respectively, and then $30 \mathrm{~g}$ of pure water was prepared for draining. Finally, $21.6 \mathrm{~kg}$ of soil was placed into test pots, each pot having a length of $40 \mathrm{~cm}$, a width of $36 \mathrm{~cm}$, and a height of $15 \mathrm{~cm}$. After planting, groundwater was applied into the pots up to $1 \mathrm{~kg}$ higher than the soil. The experimental combinations included: (1) (Ck) $30 \%$ water $+21.6 \mathrm{~kg}$ soil, (2) (EX1) $30 \%$ sericite $+21.6 \mathrm{~kg}$ soil, (3) (EX2) $40 \%$ BNS + $21.6 \mathrm{~kg}$ soil, and (4) (EX3) $40 \% \mathrm{BNS}+30 \%$ sericite $+21.6 \mathrm{~kg}$ soil. 
The rice growth data were observed and recorded (Figure 1) every 10, 20, and $30 \mathrm{~d}$ before harvesting, during which time rice samples were taken to measure the plant height, spike height, grain number, empty envelopes, saturation, panicle weight, grain weight, and empty grains.

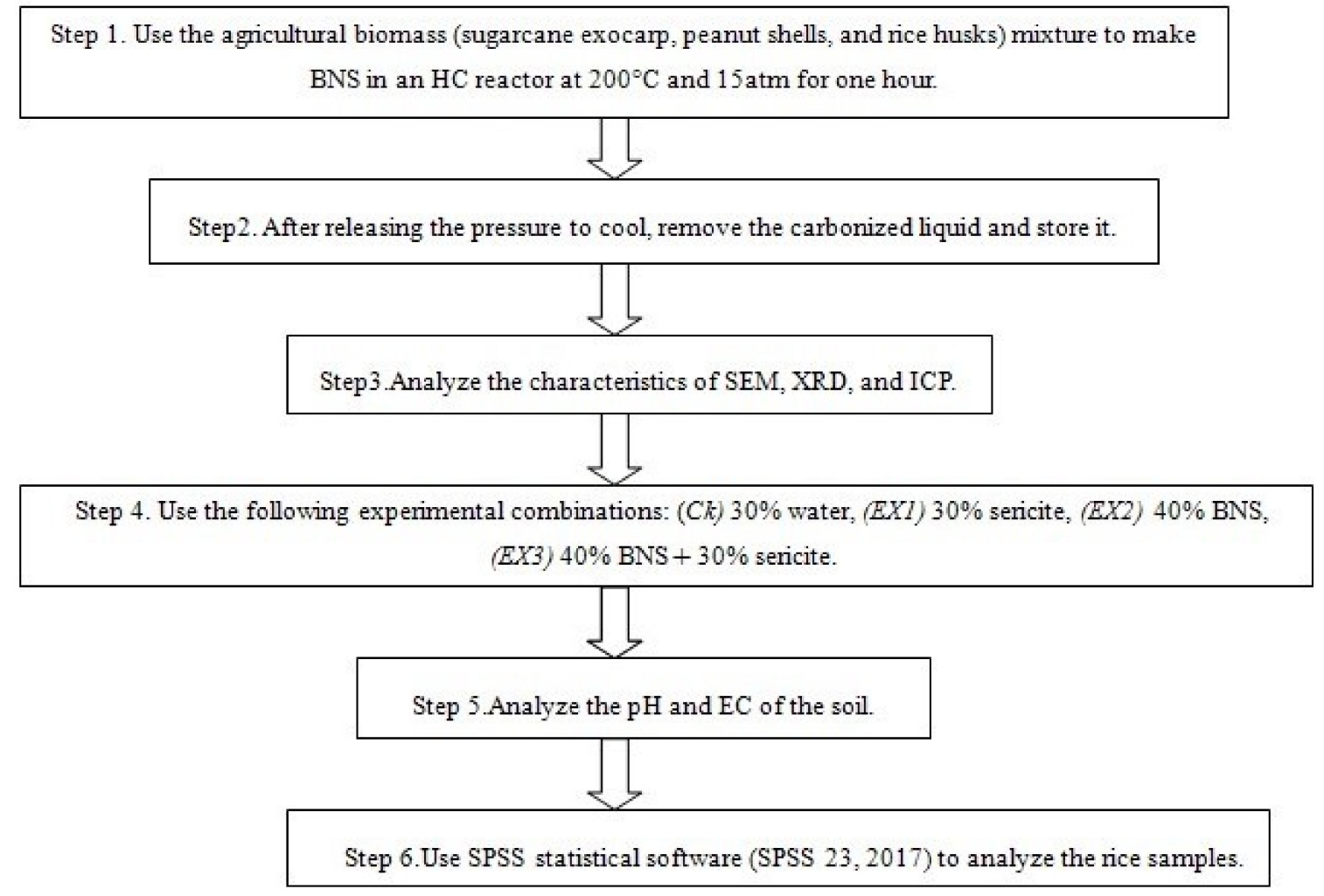

Figure 1. Experimental flow diagram.

\section{Results and Discussion}

Table 1 shows the EDX analysis data of the sugarcane exocarp, peanut shells, and rice husks used as the raw materials for the BNS. Results show that the sugarcane contained $52.64 \% \mathrm{C}$ and $0.8 \% \mathrm{Si}$, the rice husk contained $32.41 \% \mathrm{C}$ and $19.71 \% \mathrm{Si}$, and the peanut shells contained $43.78 \% \mathrm{~K}$ and $1.91 \% \mathrm{Si}$ (Table 1). The EDX analysis (Table 2) of the sericite showed that it contained $0.48 \% \mathrm{Mg}, 17.67 \% \mathrm{Al}$, $23.24 \% \mathrm{Si}, 6.57 \% \mathrm{~K}, 0.2 \% \mathrm{Ca}$, and $1.46 \% \mathrm{Fe}$. The content of the solid sericite was mainly composed of $23.24 \% \mathrm{Si}$ and $17.8 \% \mathrm{Al}$. The soil had a high $\mathrm{Si} / \mathrm{Al}$ ratio and a high $\mathrm{Si} / \mathrm{Fe}$ ratio, indicating that the plants could absorb more Si from the soil [30,31]. Figure 2 shows that the dry sericite powder had a lamellar structure with irregular vertical overlapping; the magnification of photos is about $\times 100$. Table 3 shows the calculated elemental compositions of the new synthesized fertilizer.

Table 1. Elemental compositions of sugarcane exocarp, peanut shells, and rice husks from energy-dispersive spectrometer (EDX) analysis.

\begin{tabular}{ccccccccccc}
\hline Element & $\mathbf{C}$ & $\mathbf{O}$ & $\mathbf{S i}$ & $\mathbf{N}$ & $\mathbf{K}$ & $\mathbf{C a}$ & $\mathbf{A} 1$ & \multirow{2}{*}{$\mathbf{N i}$} & \multirow{2}{*}{$\mathbf{C l}$} & $\mathbf{M g}$ \\
\hline Item & & & & & & & & \\
Sugarcane exocarp, raw & 52.64 & 46.56 & 0.80 & ND & ND & ND & ND & ND & ND & ND \\
Peanut shells, raw & 43.78 & 44.69 & 1.91 & 0.92 & 2.75 & 1.82 & 0.56 & ND & 1.66 & 1.91 \\
Rice husks, raw & 32.41 & 46.84 & 19.71 & 0.06 & 0.66 & 0.66 & ND & ND & ND & 0.06 \\
Sugarcane (BNS) & 57.00 & 41.70 & 2.00 & 0.25 & ND & 0.05 & ND & ND & ND & ND \\
Peanut shells (BNS) & 62.04 & 33.58 & 2.17 & 0.23 & 0.18 & 0.57 & 1.02 & ND & ND & 0.21 \\
Rice husks (BNS) & 50.79 & 43.51 & 4.09 & ND & ND & 0.03 & ND & 1.58 & ND & ND \\
Equally mixed BNS & 56.60 & 39.60 & 2.75 & 0.16 & 0.06 & 0.22 & 0.34 & 0.53 & ND & 0.07 \\
\hline
\end{tabular}


Table 2. Elemental compositions of sericite from EDX analysis.

\begin{tabular}{|c|c|c|c|c|c|c|c|c|}
\hline Item $\quad$ Element & $\mathrm{O}$ & $\mathrm{Na}$ & $\mathrm{Mg}$ & Al & Si & K & $\mathrm{Ca}$ & F \\
\hline$\# 1$ & 49.46 & 0.9 & 0.52 & 17.81 & 23.43 & 6.52 & 0 & 1.36 \\
\hline \#2 & 49.84 & 0.6 & 0.44 & 17.52 & 23.04 & 6.61 & 0.4 & 1.55 \\
\hline Averaged & 49.65 & 0.75 & 0.48 & 17.67 & 23.24 & 6.57 & 0.20 & 1.46 \\
\hline
\end{tabular}
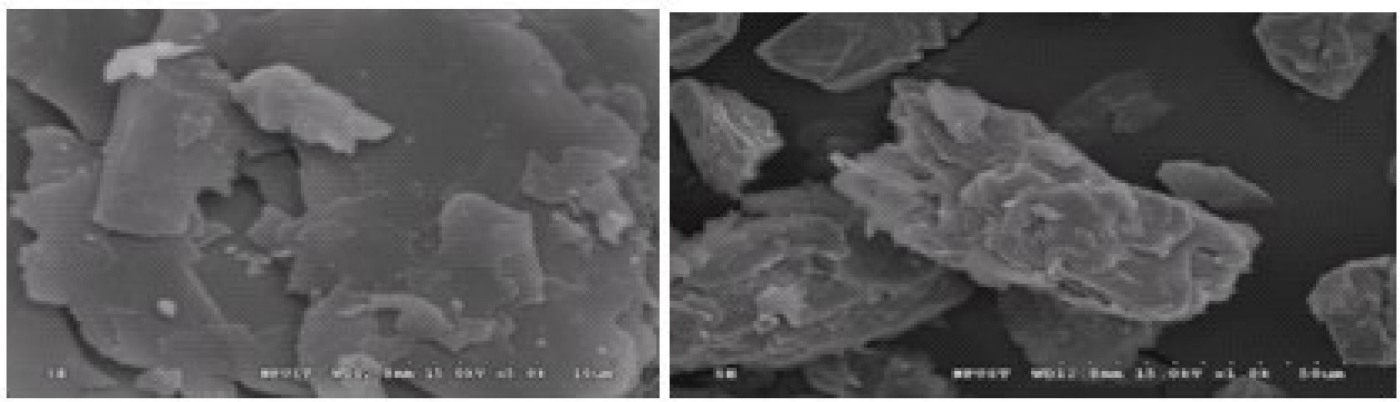

Figure 2. Scanning electron microscope (SEM) images of sericite.

Table 3. Elemental compositions of the new synthesized fertilizer.

\begin{tabular}{cccccccccccc}
\hline Element & \multirow{2}{*}{$\mathbf{C}$} & $\mathbf{O}$ & $\mathbf{N}$ & $\mathbf{K}$ & $\mathbf{S i}$ & $\mathrm{Al}$ & $\mathbf{C a}$ & $\mathbf{M g}$ & $\mathbf{N a}$ & $\mathbf{N i}$ & $\mathbf{F}$ \\
\hline $40 \% \mathrm{BNS}+30 \%$ sericite & 22.64 & 30.74 & 0.06 & 0.02 & 8.07 & 5.44 & 0.15 & 0.03 & 0.23 & 0.21 & 0.44 \\
\hline
\end{tabular}

Data calculation from Table 1; Table 2. Unit: wt\%.

The $\mathrm{pH}$ and electro-conductivity (EC) of the BNS are 7.0 and $3.5 \mathrm{us} / \mathrm{cm}$, respectively. The ICP element analysis (Table 1) revealed that the sugarcane contained $15.37 \% \mathrm{~K}$, the rice husk contained $53.28 \% \mathrm{~K}$, and the peanut shells contained $97.14 \% \mathrm{~K}$, with high contents of $\mathrm{C}$ and $\mathrm{Si}[29,30]$. Figure 3 shows that the addition of BNS and sericite increased rice plant height, number of grains, and panicle weight when compared with $\mathrm{Ck}$ (pure water only). The experimental results showed that, with the use of BNS and sericite, the rice plants had better growth performance than the control group (pure water only): (1) the rice plant height increment was $52.4 \mathrm{~cm}$, increasing from 68.6 to $121 \mathrm{~cm}$, and the degree of saturation rose by $3.9 \%$, (2) the panicle weight increased by $1.65 \mathrm{~g} / \mathrm{spike}$. It can be seen from the above results that the application of BNS in the cultivation process of rice can not only increase the plant toughness and resistance to pests and diseases, but can also increase the yield of rice and produce high-quality rice to improve economic benefits.

Figure 3 and Table 4 show the relationship between plant height and empty envelope of grain with the application of the new hybrid fertilizer. The rice plants grown using BNS and sericite are higher than the control group. The plant height of the rice increased amount by $52.5 \mathrm{~cm}$, and the empty envelope of grain increased by $12.9 \%$. The application of the new hybrid fertilizer affects the plant height and empty envelope of grains. The rice plant height and seed setting rate are positively correlated. 


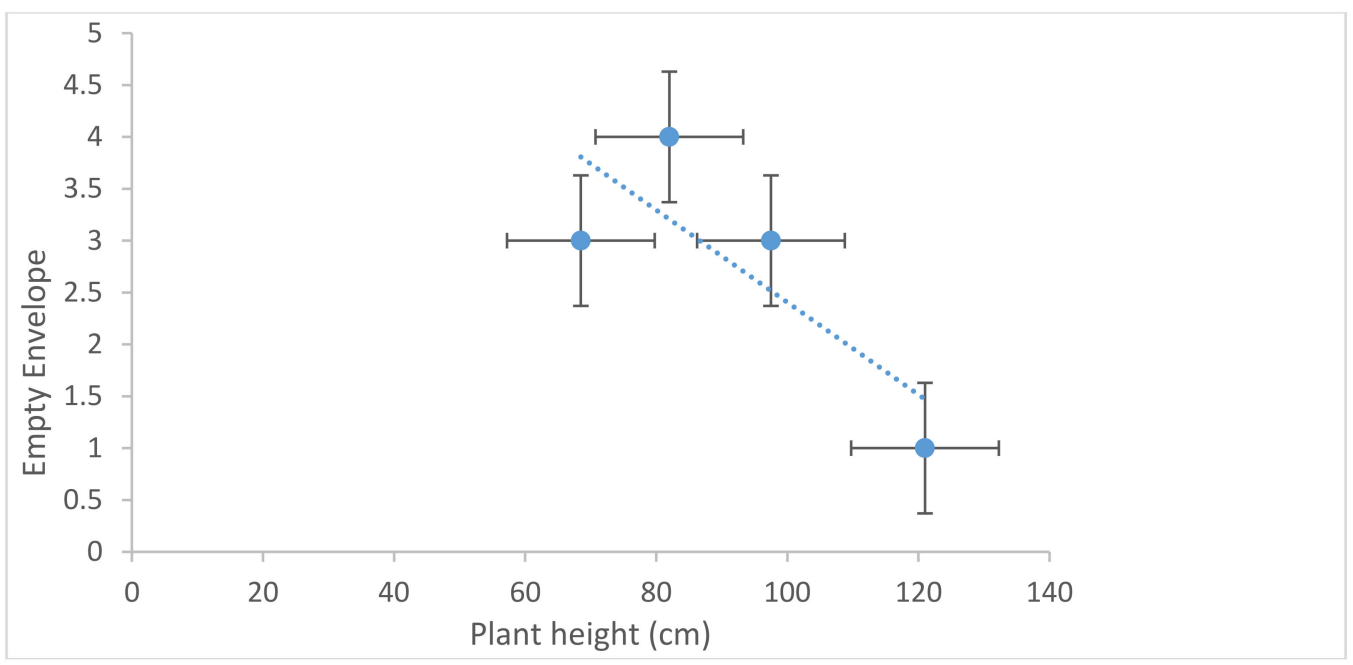

Figure 3. Relationship between plant height and empty envelope of grain: new hybrid fertilizer.

Table 4. Effects of different additives on the rice experiment.

\begin{tabular}{|c|c|c|c|c|c|c|}
\hline Item Element & $\begin{array}{l}\text { Plant Height } \\
\text { (cm) }\end{array}$ & $\begin{array}{l}\text { Spike Height } \\
\text { (cm) }\end{array}$ & $\begin{array}{c}\text { Empty } \\
\text { Envelope of Grain } \\
\text { (grain/spike) }\end{array}$ & $\begin{array}{l}\text { Saturation of } \\
\text { Spike } \\
(\%)\end{array}$ & $\begin{array}{c}\text { Seed } \\
\text { Setting } \\
\text { Rate }(\%)\end{array}$ & $\begin{array}{c}\text { Panicle Weight } \\
\text { of Grain } \\
\text { (g/spike) }\end{array}$ \\
\hline 1. (Ck) $(30 \%$ Water $)$ & 68.6 & 11.5 & 3 & 62 & 95.4 & 3.6 \\
\hline 2. (EX1) $30 \%$ Sericite & 97.6 & 12.5 & 3 & 122 & 97.6 & 4.3 \\
\hline 3. (EX2) $40 \%$ BNS & 82.0 & 13.5 & 4 & 112 & 96.6 & 3.8 \\
\hline $\begin{array}{l}\text { 4. (EX3) } 40 \% \text { BNS }+30 \% \\
\text { Sericite }\end{array}$ & 121.0 & 17.5 & 1 & 135 & 99.3 & 5.3 \\
\hline
\end{tabular}

The most important impact of this study is that we observed that when the compound fertilizer and organic fertilizer were applied, the rice growth had a very high level of empty grains, accounting for 13-21 grains/spike, and the panicle weight was 4.2-5.8 g/spike [32-34]. Although the level of empty grains may be affected by rice variety, any correlation to growth condition is not considered here. From the results, we reduced the empty grains to 1-4 grains/spike when applying the new hybrid mineral-hydrothermal fertilizer without significantly decreasing panicle weight (3.8-5.2 g/spike) or spike saturation (110-130\%). Because SPSS statistics software was not used, these experimental results need to be statistically validated. This case study shows promise at a very rudimentary level; however, further extensive studies are needed to confirm the repeatability of the results reported in this article.

\section{Conclusions}

This case report provides a new logic for circular design at the "node" point of a butterfly diagram of the circular economy proposed by the Ellen MacArthur Foundation. The Results and Discussion section in this paper is focused on the demonstration of a practical case for a circular economy; this section is not focused on the mechanism or causal factors of plant growth. Therefore, the case study indicates promising results but needs further validation with repeated experiments that can be statistically validated.

An additional future implication is how to create larger markets; this is still a big problem due to the fact that the use of recycled materials is related not only to a scientific technique, but also to the willingness of potential consumers. Cross-system matter circulation is our goal; it can address the issue of personal willingness, but it also needs a demonstration of the process from practical cases, social-benefit sand-box building, and official legislation.

Data Availability Statement: All data, models, and code generated or used during the study appear in the submitted article. 
Author Contributions: Conceptualization, methodology, M.-Y.C.; software, M.-Y.C.; validation, M.-Y.C. and W.-J.H.; formal analysis, M.-Y.C.; investigation, M.-Y.C.; resources, W.-J.H.; data curation, M.-Y.C.; writing-original draft preparation, M.-Y.C.; writing-review and editing, W.-J.H.; visualization, W.-J.H.; supervision, W.-J.H. All authors have read and agreed to the published version of the manuscript.

Funding: This research received no external funding.

Conflicts of Interest: The authors declare no conflict of interest.

\section{References}

1. Ellen MacArthur Foundation. Towards the Circular Economy. Opportunities for the Consumer Goods Sector; Ellen MacArthur Foundation: Cowes, UK, 2013; Available online: https://www.ellenmacarthurfoundation.org/ assets/downloads/publications/TCE_Report-2013.pdf (accessed on 7 February 2020).

2. Council of Agriculture. 2015. Available online: http://agrstat.coa.gov.tw/sdweb/public/inquiry/ InquireAdvance.aspx (accessed on 21 March 2018).

3. Chen, Q.; Xing, J.X.; Zheng, K.; Nan, J.S.; Wang, K. Hydrothermal Pretreatment of Lignocellulosic Materials for Improving Bioethanol Production. Pap. Biomater. 2017, 2, 51-60.

4. Lei, H.W.; Cybulska, I.; Julson, J. Hydrothermal Pretreatment of Lignocellulosic Biomass and Kinetics. J. Sustain. Bioenergy Syst. 2013, 3, 250-259. [CrossRef]

5. Nguyena, Q.A.; Yang, J.M.; Baea, H.J. Bioethanol production from individual and mixed agricultural biomass residues. Ind. Crops Prod. 2017, 95, 718-725. [CrossRef]

6. Wu, J.; Collins, R.A.; Elliston, A.; Wellner, N.; Dicks, J.; Roberts, I.N.; Waldro, K.W. Release of cell wall phenolic esters during hydrothermal pretreatment of rice husk and rice straw. Biotechnol. Biofuels 2018, 11, 162-173. [CrossRef] [PubMed]

7. Wu, Q.F.; Zhang, F.S. Progress on hydrothermal carbonization of waste biomass. Environ. Pollut. Control 2012, 34, 70-75.

8. Chun, H.K.; Chaiprapat, S.; Lee, H.K.; Hadi, P.M.; Hsu, S.C.; Leu, S.Y. Carbon sequestration potential via energy harvesting from agricultural biomass residues in Mekong River basin, Southeast Asia. Renew. Sustain. Energy Rev. 2017, 68, 1051-1062.

9. Wang, Z.W.; Zhu, M.Q.; Li, M.F.; Wang, J.Q.; Wei, Q.; Sun, R.C. Comprehensive evaluation of the liquid fraction during the hydrothermal treatment of rapeseed straw. Biotechnol. Biofuels 2016, 9, 142. [CrossRef]

10. Capolupo, L.; Faraco, V. Green methods of lignocellulose pretreatment for biorefinery development Laura. Appl. Microbiol. Biotechnol. 2016, 100, 9451-9467. [CrossRef]

11. Ren, M.; Yin, H.B.; Hang, Y.G.; Zhang, Y.S.; Wang, A.L.; Yu, L.B.; Jiang, T.S.; Wu, Z.N. Deposition of colored inorganiccoatinglayers on lamellar sericitesurface and the pigmentary performances. Powder Technol. 2011, 214, 31-37. [CrossRef]

12. Ren, M.; Yin, H.B.; Lu, Z.; Wang, A.L.; Yu, L.B.; Jang, T.S. Evolution of rutile TiO2coatinglayers on lamellar sericite surface induced by Sn4+the pigmentary properties. Powder Technol. 2010, 204, 249-254. [CrossRef]

13. Hsiao, Y.H.; Guo, T.C.; Ray, D.T.; Tsai, Y.L.; Yang, H.S. A Study on Metal Oxide Coating on Sericite. Min. Metall. China Metall. Eng. Soc. J. 2016, 233, 57-82. (In Chinese)

14. Hu, B.; Hu, Q.; Xu, D.; Chen, C.G. Macroscopic and microscopic investigation on adsorption of Sr (II) on sericite. J. Mol. Liq. 2017, 225, 563-568. [CrossRef]

15. Jeon, C. Removal of cesium ions from aqueous solutions using immobilized nickel hexacyan of errate-sericite beads in the batch and continuous processes. J. Ind. Eng. Chem. 2016, 40, 93-98. [CrossRef]

16. Tiwari, D.; Kim, H.U.; Lee, S.M. Removal behavior ofsericitefor $\mathrm{Cu}$ (II) and $\mathrm{Pb}$ (II) from aqueous solutions: Batch and column studies. Separ. Purif. Technol. 2007, 57, 11-16. [CrossRef]

17. Tiwari, D.; Lee, S.M. Surface-functionalized activated sericite for the simultaneous removal of cadmium and phenol from aqueous solutions: Mechanistic insights. Chem. Eng. J. 2016, 283, 1414-1423.

18. Pawar, R.R.; Hong, S.M.; Jin, K.J.; Lee, S.M. Iron-oxide modifiedsericitealginate beads: A sustainable adsorbent for the removal of $\mathrm{As}(\mathrm{V})$ and $\mathrm{Pb}$ (II) from aqueous solutions. J. Mol. Liq. 2017, 240, 497-503.

19. Choi, H.J. Application of methyl-esterified sericite for harvesting microalgae species. J. Environ. Chem. Eng. 2016, 4, 3593-3600. [CrossRef]

20. Cuong, T.X.; Ullah, H.; Datta, A.; Hanh, T.C. Effects of Silicon-Based Fertilizer on Growth, Yield and Nutrient Uptake of Rice in Tropical Zone of Vietnam. Rice Sci. 2017, 24, 283-290. [CrossRef] 
21. Islam, M.A.; Obour, A.K.; Saha, M.C.; Nachtman, J.J.; Cecil, W.K.; Baumgartner, R.E. Grain Yield, Forage Yield, and Nutritive Value of Dual-Purpose Small Grains in the Central High Plains of the USA. Crop Manag. 2014, 12, 1-8. [CrossRef]

22. Pati, S.; Pal, B.; Badole, S.; Hazra, G.C.; Mandal, B. Effect of Silicon Fertilization on Growth, Yield and Nutrient Uptake of Rice. Commun. Soil Sci. Plant Anal. 2016, 47, 284-290. [CrossRef]

23. Madić, M.; Knežević, D.; Paunović, A.; Đurović, D. Plant height and internode length as components of lodging resistance in barley. Acta Agric. Serbica 2016, 42, 99-106.

24. Zhang, Y.; Yu, C.; Lin, J.; Liu, J.; Liu, B.; Wang, J.; Huang, A.; Li, H.; Zhao, T. OsMPH1 regulates plant height and improves grain yield in rice. PLoS ONE 2017, 12, e0180125. [CrossRef] [PubMed]

25. Lavinsky, A.O.; Detmann, K.C.; Reis, J.V.; Ávila, R.T.; Sanglard, M.L.; Pereira, L.F.; Sanglard, L.M.; Rodrigues, F.A.; Araújo, W.L.; DaMatta, F.M. Silicon improves rice grain yield and photosynthesis specifically when supplied during the reproductive growth stage. J. Plant Physiol. 2016, 206, 125-132. [CrossRef]

26. Moe, K.; Htwe, A.Z.; Thu, T.T.P.; Kajihara, Y.; Yamakawa, T. Effects on NPK Status, Growth, Dry Matter and Yield of Rice (Oryza sativa) by Organic Fertilizers Applied in Field Condition. Agriculture 2019, 9, 109. [CrossRef]

27. Meena, V.D.; Dotaniya, M.L.; Coumar, V.; Rajendiran, S.; Kundu, S.; Rao, A.S. A Case for Silicon Fertilization to Improve Crop Yields in Tropical Soils. Proc. Natl. Acad. Sci. India Sect. B Biol. Sci. 2014, 84, 505-518. [CrossRef]

28. Xu, J.K.; Yang, L.X.; Wang, Y.L.; Wang, Z.Q. Advances in the Study Uptake and Accumulation of Heavy Metal in Rice (Oryza sativa) and its Mechanisms. Chin. Bull. Bot. 2005, 22, 614-622.

29. Chang, M.Y.; Huang, W.J. Production of Silicon Carbide Liquid Fertilizer by Hydrothermal Carbonization Processes from Silicon Containing Agricultural Waste Biomass. Eng. J. 2016, 20, 11-17. [CrossRef]

30. Chang, M.Y.; Huang, W.J. Hydrothermal Biorefinery of Spent Agricultural Biomass into Value-added Bioneutrient Solution: Comparison between Greenhouse and Field Cropping Data. Ind. Crop. Prod. 2018, 126, 186-189. [CrossRef]

31. Ma, J.F.; Yamaji, N. Silicon uptake and accumulation in higher plants. Trends Plant Sci. 2006, 11, 392-397. [CrossRef]

32. Akhmad, A.; Dewi, W.S.; Sagiman, S.; Suntoro, S. The effect of mixed liming and NPK fertilizer to yield of some rice varieties on new openings of acid sulfate tidal swamp land. IOP Conf. Ser. Earth Environ. Sci. 2018, 142, 012078. [CrossRef]

33. Budiono, R.; Adinurani, P.G.; Soni, P. Effect of new NPK fertilizer on lowland rice (Oryza sativa L.) growth. IOP Conf. Ser. Earth Environ. Sci. 2019, 293, 012034. [CrossRef]

34. Thavanesan, S.; Seran, T.H. Effect of Rice Straw and Husk Biochar on Vegetative Growth and Yield Attributes of Oryza sativa L. Int. J. Crop Sci. Technol. 2018, 4, 49-56. 